\title{
Social movement, public policy changes and partnerships building for local
} development

\author{
Movimento social, mudanças na política pública e construção de parcerias para o \\ desenvolvimento local \\ Movimiento social, cambios en las políticas públicas y construcción de asociaciones \\ para el desarrollo local \\ Mouvement social, changements dans les politiques publiques et création de partenariast pour \\ le développement local
}

\author{
Mário Vasconcellos* \\ Ana Maria Vasconcellos**
}

Recebido em 20/02/2011 revisado e aprovado em28/05/2011; aceito em 16/06/2011

\begin{abstract}
The paper debates the rural social movement's influence on policy changes for small-scale rural producers and the creation of partnerships between Government and Local Organizations for local development in Amazonia, particularly in Pará state. The paper's goal is to examine partnership as a result of an interactive process of both changes of public policies and the demands of social movements. The paper shows that although social movements are part of a relation of conflict between state and society, in Pará they were a precondition for changes in public policy, financing and in the priorities of regional agencies that resulted in propositions for cooperation between local Government and Local Organizations at município level.
\end{abstract}

Key words: Social Movement. Partnership. Local Development.

Resumo: O artigo discute a influência do movimento social rural sobre as mudanças na política de apoio ao pequeno produtor rural e para a criação de parcerias entre o Governo e as Organizações Locais para o desenvolvimento local na Amazônia, em particular no estado do Pará. O objetivo do artigo é examinar a parceria como um resultado de um processo interativo entre as mudanças nas políticas públicas e as demandas dos movimentos sociais. $\mathrm{O}$ artigo mostra que embora os movimentos sociais façam parte de uma relação conflituosa entre o Estado e a sociedade civil, tais movimentos no estado do Pará foram uma pré-condição para mudanças na política pública, estrutura de financiamento e prioridades das agencias regionais que resultaram em proposições para cooperação entre o Governo e as Organizações Locais em nível municipal.

Palavras-chave: Movimento Social. Parceria. Desenvolvimento Local

Resumen: El artículo analiza la influencia de los movimientos sociales rurales en los cambios de política de apoyo al pequeño productor rural y en la creación de asociaciones entre el Gobierno y las Organizaciones Locales para el desarrollo local en la Amazonía, particularmente en el Estado de Pará. El objetivo del artículo es examinar la asociación como resultado de un proceso interactivo entre los cambios en las políticas públicas y las demandas de los movimientos sociales. El artículo muestra que aunque los movimientos sociales son parte de una relación de confrontación entre el Estado y la sociedad civil, los movimientos de este tipo en el Estado de Pará, fueron una condición previa para cambios en las políticas públicas, la estructura de financiación y prioridades de los organismos regionales que resultaran en propuestas para la cooperación entre el Gobierno y las Organizaciones Locales a nivel municipal.

Palabras clave: Movimiento Social. Asociación. Desarrollo Local.

Résumé: L'article traite de l'influence du mouvement social rural sur les changements dans la politique d'appui au petit producteur rural et la création de partenariats entre le Gouvernement et les Organizations Locales afin de promouvoir le développement local en Amazonie, particulièrement dans l'Etat du Pará. L'objectif de l'article est d'examiner le partenariat comme le résultat d'un processus interactif entre les changements des politiques publiques et les demandes des mouvements sociaux. L'article indique que, bien que les mouvements sociaux fassent partis d'une relation conflictuelle entre l’Etat et la société civile, ces mouvements dans l’Etat du Pará constituent une précondition pour les changements de la politique publique, de la structure de financement et des priorités régionales qui résultent en propositions de coopération entre le gouvernemenrt et les organizations locales sur le plan municipal.

Mots-clés: Mouvement Social, Partenariat, Développement Local.

\footnotetext{
* He is an economist and holds a M.Phil from the Centre of Advanced Studies, Federal University of Pará (Brazil) and $\mathrm{PhD}$ in Development Studies from the Swansea University (United Kingdom). He is a lecturer at Federal University of Pará - UFPA (Natural Resources Management and Local Development Postgraduate Programme, from the Centre of Environment - NUMA) and a senior lecturer at University of Amazonia - UNAMA (Administration Postgraduate Programme).Emails: mariovasc@ufpa.br; mariovasc@unama.br

** She is a sociologist and holds a M.Phil. from the Centre of Advanced Studies, Federal University of Pará (Brazil) and PhD in Development Studies from the Swansea University (United Kingdom). She is a senior lecturer at University of Amazonia and coordinator of the UNAMA's Administration Postgraduate Programme. Email: annavasc@unama.br
} 


\section{Introduction}

This paper deals with the rural social movement's influence on public policy changes for small-scale rural producers and the creation of partnerships between Government and Local Organizations (associations, cooperatives, workers unions) for rural development in Amazonia, particularly in Pará state. The paper's aim is to examine partnership as a result of an interactive process of both changes of public policy (top-down state action) and the demand of social movements (bottom-up demand).

The paper is part of a broader research that attempts to further understanding of the relationship that have emerged between local government and local organizations in the implementation of local development programmes at municipal level in Brazil. The research focuses specifically on four municípios (Igarapé-Miri, Ourém, Mojú and Santo Antonio do Tauá) of Pará state in the Brazilian Amazonia. The research explores to what extent partnership is an effective strategy for local development in areas of historical conflict between local government and family-based, small-scale producers. In doing so, the work uses a multiple case study as a main research method.

Through a historical analysis, the paper reconstitutes the socio-political scenario that influenced the formation of partnerships in Igarapé-Miri, Ourém and Mojú. The paper shows that partnership between local government and local organisation in Pará emerged as a new model of public policy for the rural sector. In its turn, this new model was a result of the struggles that rural social movement carried out against regional and federal government for the inclusion of family-base, small-scale rural producers in regional development policy. Although social movements are part of the relationship of conflict between Government and rural society, in Pará they were a precondition for changes in public policy and in further propositions for cooperation between local organization and local government at município level.

This paper is organized into five sections including this initial one. The second section deals with two of the factors that act on partnership building that are social capital and social networks. The aim of the second section is to show how partnership emerges from the influence of both societal structure and the roles of the state. The third section discusses the Rural Workers' Union Movement (MSTR) and the rural workers' unions in Pará as the basis for the construction of rural workers social capital. Then, the third section explains the link that has existed between the social movement and the modification of public policy. The fourth section focuses on the case studies and deals with political competitiveness and the context of state-local organisation partnerships in the municipios of Igarapé-Miri, Ourém and Moju. Finally, the fifth section raises some conclusions about the influence of social movements on policy changes and partnership building for rural development.

\section{Partnership, Social Capital and Social Networks}

The reassessment of the relationship between state and civil society through the theory of social capital throughout the 1990s (COLEMAN, 1990; PUTNAM, 1993; EVANS, 1997; FOX, 1997) raised the suggestion that organisational and institutional constraints from individual social networks, contribute to inefficient political structures, economic fragility and social fragmentation. Social capital in Coleman's (1990) and Putnam's (1993; 2002) terms relate to features of social life such as trust, norms and social networks that facilitate co-ordinated action and enable participants to act more effectively to follow shared objectives.

In spite of the arguments that any society is characterized by networks of interpersonal communication and exchange, both formal and informal as stated by Coleman (1990) and Putnam (1993), an understanding of how social capital has impacted societies shaped by recent history has not been recurrent. Studies of civic organizations with public engagement and its socio-political and economic effects (COLEMAN, 1990; PUTNAM, 1993 ; 2002) have been mostly concentrated on advanced industrial countries. These studies have pointed out that the capacity of a society to produce social capital among its citizens is supported by its long-term experience of 
social organisation. However, for societies formed from a recent history, as argued by Fox (1997) and Vasconcellos Sobrinho (2009), trust, norms of reciprocity and social networks are rare and social capital is substituted by hierarchical politics.

The few studies of societies with an absence of trust such as Isham et al. (2002) emphasise the role of social capital in overcoming market failures and democracy. So far, studies on social capital in developing countries have been more oriented towards the economic and political effects of social capital (TENDLER, 1997; BEBBINGTON, 1999; ISHAM et al., 2002) and analyses about the mechanisms through which these effects happen are still rare.

In Latin America, where the absence of trust and social engagement are great as argued by Fox (1997), analyses on social capital focus on interaction between Government and civil society as part of a strategy to stimulate improved service provision by the Government (TENDLER, 1997). Additionally, it has focused on the conflicting relationship between Government and citizenry in less than democratic conditions (FOX, 1995; 1997). At present, social capital analysis in Latin America has been towards the importance of social networks for public outcomes (TENDLER, 1997; BEBBINGTON, 1999) rather than on the mechanisms through which these networks are created.

In spite of some literature (FOWLER, 1997; GILCHRIST, 2004) that indicates that there is a direct correlation between social capital and partnership, so far it is not clear if a social network of one group of organizations is any more effective than the social network of another group of organizations to work in partnership and promote development (BOWYER, 2003).

In areas of strong vertical social structures based on relationships of authority and power, it is stated that the potential of ordinary people and their organizations to have collective action is more restricted (PUTNAM, 1993; FOX, 1997; BOWYER, 2006). The level of social trust and the operational capacity of social networks to bring about fundamental changes to the structures of politics and social relations is weakened. It suggests that the impact of hierarchy and social fragmentation upon the operational capacity of social networks and the level of social trust are critical (FOX, 1997). In this respect, it is relevant to enquire whether social networks are a valid method for improvements if citizens' capacity for collective action is restricted and access to and influence over state and market is not feasible. Social networks should be analysed in order to show how much they themselves have the capacity to influence the formation and the support of partnership with the Government sector for the improvement of the rural sector.

There are a number of influences on the capacity of social networks to give ordinary people the means to defend mutual interests and challenge authority. First among these is a lack of clarity about the relationship between member organizations inside a social network (FARRINGTON; BEBBINGTON, 1993). It is argued that interaction is predicated upon regular exchange of information shared by all the various member organizations. Secondly, physical and social constraints weaken information access (PUTNAM, 1993). It is stated that the context in which the interaction occurs is as important as the consequences that it has and the changes that it suggests. Thirdly, practical difficulties such as geography, location, and transport influence the dissemination of information (BOWYER, 2005, p. 484). Finally, the type and quality of information available to member organizations inside a social network is also vital (SEN, 1999, p. 56). For these two last factors, it is stated that the type of information presented to member organizations in a social network is subject to the negative influence of difficulties of geographical access, transport and communication. Bowyer (2005, p. 484) for example, states that geographical discrimination, remoteness, location, transport and communication make rural communities more vulnerable to poverty. This indicates that the capacity of social networks to act effectively does not depend only on the information to which each member has access, but also on the practical difficulties that influence the dissemination and the quality of that information.

It is also pointed out that the single greatest obstruction of effective social networks derives from the political effects that emerge when they seek to generate extensive trust, 
particularly across a fragmented social and economic environment (OAKLEY, 1995; FOX, 1997). It is argued that a number of political transformations are required to allow excluded groups of rural people to take part in decision making, political action and policy development (OAKLEY, 1995; ENGBERGPEDERSEN; WEBSTER, 2002).

To this end, the commitment to organisational restructuring and the support of the creation of organisational mechanisms to promote decentralised and multiple-stakeholder decision making are relevant factors for further examination. This is the aim of the following section. It shows an example of a process of social capital building from social movement. Particularly, the next section shows the influence of the Rural Workers' Union Movement influence on public policy changes in Amazonia.

\section{Social Capital Building and Public Po- licy Changes}

\subsection{Social Capital Basis: The Rural Workers' Union Movement}

The Rural Workers' Union Movement (MSTR) in Amazonia emerged during the 1980s (GRZYBOWSKI, 1987). It was created by the Amazonian rural workers' unions to contest the policy of development implemented in Amazonia during the dictatorship period. Key issues for the movement included rural infrastructure, distribution of land and access to credit (GRZYBOWSKI, 1987). Since then, the movement has been part of a broader struggle both within and outside the official union apparatus to develop more representative worker union organizations. Both local and national level parties have been central in shaping the trajectory of the Amazonia movement as an example of the 'new unionism' in rural areas of Brazil (TURA, 1996).

The Amazonian movement is also striking in its unusual capacity to unify a geographically-scattered peasantry of diverse origins (TURA, 1996). The rural social movement in the Pará state and in Amazonia as a whole included different types of peasants who live in diverse rural zones and have distinct cultural traditions, histories and modes of work and life (GRZYBOWSKI, 1987). For instance, the floodplain (várzea) rural workers in Pará for the most part are descendents of indigenous people (caboclos) of ancient origin from Pará itself (Igarapé-Miri and Moju are two typical cases). In the north east of Pará, the peasant population is formed by miscegenation of people from Pará itself and people from the north east of Brazil particularly from the states of Maranhão, Ceará and Rio Grande do Norte (as the case of Ourém).

The rural conflicts in Pará that began to emerge in the early 1970s were as geographically dispersed and socially fragmented as the rural workers themselves (GRZYBOWSKI, 1987). New social contradictions emerged with the rising poverty and new social forces grew, induced by federal Government intervention in Pará and in Amazonia as a whole, particularly from the Government's programme of financial incentives for large projects (VASCONCELLOS, 1996).

The Rural Workers' Unions in Pará were created in the beginning of the 1970s as elsewhere in rural Brazil, not from the workers' initiatives but from the influence of federal Government involved in the Rondon Project and the labour regional offices that aimed to organize and control rural labour (TURA, 2000). Under the military Government's dictatorship structure, the Rural Workers' Unions were politically controlled by forces linked to the traditional oligarchs. At that time, legislation required that all union organizations in Brazilian rural areas be channelled through state-sponsored union organizations (GRZYBOWSKI, 1987). According to the then legislation, the Rural Workers' Unions were to be formed at municipal level, the membership comprising wage labourers, different categories of peasants and family farms (DALLA-NORA, 2002). The official structure of organized rural labour included these local rural unions, state-level federations of rural workers and the national confederation of agricultural workers. The military's clientelist social welfare system called FUNRURAL also served as a powerful incentive to form official unions since it was these unions that distributed benefits at local level, turning the rural workers' organizations into extensions of state power (TURA, 2000b, p. 274).

The corporatist allegiance of the official unions to the state, both before and after the 
transition, frustrated rural workers' demands for genuine representation (TURA, 2000b). Conflicts between official and worker-controlled unions have their origins when a 'new unionism' (TURA, 1996) began to emerge in the cities about the end of the 1980s, particularly in the industrial heartland. At the same time in Pará, a new movement linking diverse struggles was gaining momentum as rural workers began to create alliances and to seek broader support. Both the non-governmental Federation of Social and Education Assistance Agencies (FASE) and individuals within the Catholic Church were very important to the movement in encouraging meetings and study groups. Local groups included union delegations with the direct participation of rural workers. Fieldwork research identified that FASE was very active in both Ourém and Igarapé-Miri. In Igarapé-Miri and Moju, members inside the Catholic Church were extremely important in building up the rural social movement.

In the State of Pará there were exemplary cases of peasants taking over their own unions, often through a struggle in which they put themselves as the collective subject 'rural workers' and renewed the union movement. As elsewhere in Brazil where the local rural workers' union was either passive or hostile, the very dynamics of the Pará movement led to a struggle with the entrenched interests for control of the unions. In many respects, Pará is the rural version of the new unionism in Brazil (TURA, 1996). The movement faced many challenges simultaneously: defining its own identity, operating as a union, facing attacks from powerful and often violent adversaries in land struggles (ibid) and offering protection to powerless people.

\subsection{Public Policy Changes for Rural Area in Amazonia}

The 1988 Brazilian Constitution defined new mechanisms of federal and regional resource transference to Brazilian municipios. One of the purposes of the new mechanisms was to allocate resources in areas where external support for their development was necessary. Although such a pattern overturned the previous model adopted by the Federal Constitution created in the dicta- torship period (1964 - 1985), in practice the new mechanisms alone have not been able to solve the power imbalance between regional and local governments and to decentralise resources effectively to underdeveloped areas (OLIVEIRA; DOMINGUES, 2005). Transference of resources without transference of political autonomy to local Government to act according to local circumstances can lead to resources not being available to meet local priorities and interests.

However, despite these issues, the $\mathrm{Mu}$ nicipalities Participation Fund (FPM) and the Constitutional Funds for Financing (FC) were two of the innovative forms of the transference of resources to municipios adopted by the 1988 Constitution. The first provide direct credit to local Government administrations. In the latter the credit is transferred to private enterprises. Both are significant to the municipal economy. At present, the FPM is the most important source of credit for the $81 \%$ of Brazilian municipios with less than 30,000 inhabitants (BNDS, 2001; IBAM, 2008) and the FNO (Constitutional Fund for Financing the Northern Region) is one of the principal mechanisms of credit support for projects in underdeveloped regions (BASA, 2002). In fact, the FNO is the version of the constitutional fund for the northern region in Brazil. Although the FNO only totals $0.6 \%$ of fiscal income, it represents the most important financial mechanism for small producers in the whole of the Brazilian Amazonia in terms of amount of resources and number of businesses involved (BASA, 2002).

Although the FNO can be characterized simply as a differentiated credit policy that prioritises regional needs (BASA, 2002), there are also other factors that characterise it. One factor is that the FNO is an outcome of the intensive mobilization of different regional parties that have contested the imbalanced results of the regional development plans and projects of federal Government, notably those from the military Government dictatorship of 1964 onwards (1964 - 1985) (TURA, 1996; 2000a). Social movements and specifically rural social movements have played an important role in policy changes (GRZYBOWSKI, 1987; TURA, 1996, 2000a; TURA; COSTA, 2000). They have been identified as an important force for the protection of the 
most vulnerable rural people (GRZYBOWSKI, 1987). How the movement has acted to protect the interests of the most vulnerable rural people and how it has confronted the state to defend those interests gives an understanding of the present pattern of relations between the (regional and local) Government and the local organizations at municipal level. One of the examples was the creation of the FNO Rural-Especial in 1993 during the second phase of the FNO (first phase: 1989 - 1992; second phase: 1993 - 1996). This phase was characterized by a growth in support to micro beneficiaries (TURA, 2000, p. 43). $80 \%$ of the beneficiaries between 1993 and 1996 were micro beneficiaries (BASA, 2002). Although BASA documents states that the banks took the initiative to create a credit line designated to support small producers "revolutionizing rural credit in Brazil" (BASA, 2002), its creation was certainly influenced by political and social pressure from the MSTR (Rural Workers' Union Movement).

[...] If BASA had created the FNO-Special by itself we would not have joined the rural workers, to spend our nights in the Republica square, to confront the police and to see our friends injured inside the bank office [...] I am sure that with no rural workers union we would still be excluded from the beneficiaries of the fund [...]. (Leader of a Local Organisation in Igarape-Miri).

Focusing particularly on the FNO, the MSRT demanded a reformulation of the criteria established by BASA in offering finance from the FNO. Initially, the FNO's conditions created by BASA were not different from the usual rural credit. The conditions, which included land warranty and expensive taxes, were barriers preventing small-scale lowincome peasants from getting credit access. The rules elaborated by BASA were not compatible with the constitutional fund's original goals. They did not offer a different policy of credit and did not match the needs of smallscale, low-income rural producers. Firstly, BASA defended the primacy of economic efficiency over the use of labour. Secondly, the bank created a plethora of bureaucratic procedures and legal requirements to approve loans, turning the FNO into a fund practically inaccessible to those who could not afford to pay an accountant or a solicitor (TURA, 2000a, p. 35). Although the FNO's scope had been enlarged to accommodate both large farmers and low-income, small-scale rural producers, its first phase privileged the traditional economic elites rather than the traditionally excluded rural groups (ibid).

The demand was carried out by MSTR through political and social protests called Gritos (Screams). This mobilization, also called Gritos da Terra (Screams of the Land) demanded changes in the FNO's use of red tape and conditions. The Gritos' demands occurred in 1991 (twice), 1993 and 1994 and gradually influenced FNO changes in conditions and amount of paperwork and thus enabled more credit access for small-scale low-income producers. In spite of their mixed political roles, the Gritos were social movements that offered possibilities for peasants to be constructive agents in an agrarian policy predominated by larger farmers (MONTEIRO, 1996; TURA, 1996).

[...] Everything that we got was by 'shouting' [...] we spent three days and three nights in front of the bank when they [bank staff] promised to establish the FNO-special [...]. (Former head of the Rural Workers' Union, Igarape-Miri).

The first Grito in 1991 was organized with diffuse aims and did not accomplish tangible gains in terms of the FNO. It was organized to protest against rural violence and the murder of dominant rural leaders. Although the discussion about rural credit was placed on the agenda, the lack of clear proposals did not allow the debate to progress. At that time, bank rules were supported by 'representative' organizations in the process of regional development (ibid), although the meaning of 'representative' was never clear. These organizations were SUDAM, SUFRAMA, CEPLAC, EMATER and the Secretaries of State for Agriculture, Planning, Commerce and Industry. However, BASA's resistance to change $\mathrm{FNO}^{\prime}$ 's rules encouraged the movement to turn against the bank.

The second Grito also took place in 1991. It was focused on FNO and BASA and although meetings with representatives of the state executive, legislative and judiciary powers took place, the executives of BASA felt the pressure directly and opened negotiations. As a result of the discussions, BASA's executives opened a credit line called FNO-Urgent 
(1991 - 1992) for small producers. This credit line was designed to meet the needs of those who could not offer guarantees to the traditional banks. Both rural movements and bank officials agreed (for different reasons) that the loans should be made through associations for rural communities. The union leaders supported this proposal as they believed that this would strengthen their movement and engage more rural workers in some form of collective action. Bank officials, on the other hand, believed that through this procedure, associations could offer some kind of collective warranty, which if not tangible was at least moral. This rule, when established, became one of the most influential mechanisms later on in partnership formations between local organizations and agents of the state, since most associations in Pará were created to accommodate $\mathrm{FNO}$ requirements.

The main issues of the third Grito in 1993 were the extension of the FNO to other Amazonian states and a simplification of the FNO-Urgent rules (desburocratização). From 1994 onward, the Gritos became a nationwide protest and were renamed Gritos da Terra Brasil (Screams of the Brazilian Land). In Amazonia, its title was changed to Grito da Amazonia (Screams of Amazonia). At present, once a year the Grito da Amazonia is carried out with both broad and specific agendas.

One of the most important gains for the movement at national level was the creation of a new credit programme for small-scale, low-income agricultural producers called National Support Programme for Family-based Agriculture (PRONAF) established in 1996. The Rural Workers' Movement negotiated the creation of PRONAF with the Ministry of Agriculture and the Banco do Brasil (Bank of Brazil plc.) which manages the programme.

In the following years, the rural movement at regional level continued to fight BASA for more advantageous conditions for loans and an extension of the programme. At regional level, the PRONAF was incorporated as priority of FNO-Special (1993 replacement for the FNO-Urgent). What is interesting in this struggle between the banks and the rural movement is that the latter increased their effort year after year making their claims more focused and pro-active. The Gritos represented a consolidation of the alliances made by the rural workers during the previous mobilization and was also a partnership between agents of the state and local organizations.

If on the one hand, social movements were efficient political mechanisms to revise traditional public policy for rural development (firstly at regional level and later at national level), on the other hand the results achieved required existing models of local organizations (and the movement itself) to be reconfigured. Up to that time, the model for local organizations in the region was based on workers' unions (the rural unions) that from the 1980s on had been in political confrontation with the different spheres of Government.

However, both the reformulation of the FNO's conditions to suit small producers and the implementation of FNO-Special and PRONAF demanded the formation of communitybased associations as the mechanism for small producers to access credit. As a result, in Pará the number of community-based associations increased substantially from 45 at the end of 1980 s to 1,363 at the end of 1995 (TURA, 2000). Up-to-date official statistics about community-based associations in Pará from 1995 onward were not available when this work was written. However, the evolution of community-based associations in IgarapéMiri, Ourém and Moju indicates that most associations were created from 1996 onward. This study identified that the majority of associations were created with the sole aim of getting credit. This study identified that four associations in Ourém, five associations in Igarapé-Miri and five associations in Moju ceased activity when they achieved this goal. It means that creation of new associations per se has no necessary impact on social structure.

The reconfiguration of local organizations is therefore an outcome of tangible needs that came about from the conditions established for credit acquisition. The growth of local organizations in the rural sector may be interpreted as a development of social capital.

In spite of the great distance between the needs of rural producers and the volume of resources applied (MATTEI, 2001), since 1997 PRONAF has been the most important credit programme for small-scale low-income agricultural producers in Brazil (ABRAMO- 
VAY, 2002; VASCONCELLOS SOBRINHO, 2009) and particularly in Pará.

At present, the programme is managed by the Family-based Agriculture Department (SAF) which is linked to the Ministry of Agrarian Development (MDA). The Department was specifically created to support familybased agriculture as a way of promoting sustainable, local (municipal) development under principles of decentralisation, democracy, transparency, partnership and social responsibility.

PRONAF's aims are especially focused on supporting family-based agriculture infrastructure and productive performance. The programme is divided into three subprograms: (1) rural credit for small producers, (2) rural worker capacity building and (3) infrastructure and municipal service support. The first subprogram focuses exclusively on credit for planting and harvesting. The second subprogram deals with labour development in terms of organisational and work capacities. The third subprogram is for municipal infrastructure improvement in terms of goods and services.

The third subprogram started in 1997 and its execution is distinct from the other subprograms. To take part in the third subprogram each municipality must create its own Municipal Committee for Rural Development (CDMR), a Rural Development Programme (PDR) and its own agenda of implementation. In federal design there is a belief that these planning tools have a positive influence on rural communities and local state cooperation and consequently on rural outcomes, irrespective of the various factors that influence its final outcome.

PRONAF's strategies are based on partnership between federal, regional and municipal entities, private sector and familial agricultural workers and their local organizations. (Art. $2^{\circ}$, Federal Decree $n$. 3991 of 30/10/2001).

In PRONAF there is also a belief that participation by local organizations in rural planning and implementation leads to a greater level of efficiency and effective investments and helps to promote greater democracy in the rural sector (ABRAMOVAY, 2002). In fact, local organisation participation in rural planning and implementation has been described in official documents and in political discourse as 'partnership' between the state and civil society.

Partnership between PRONAF's executor agents and programme beneficiaries in the actions of planning, implementation e monitoring. (Art. $4^{\circ}$, item 4, Federal Decree No. 3991 of 30/10/2001).

In practice, PRONAF has been criticised for an absence of articulation between its subprograms (ABRAMOVAY, 2002) and its management structure. However, the programme has been commended for bringing the different rural actors together (from public sphere and civil society) to elaborate, implement and evaluate a plan of common interests and to lead the way in efficiency and effectiveness for the use of public resources (MATTEI, 2001).

\section{Partnership Building and the Internal Context in Igarapé-Miri, Mojú and Ourém}

Partnership between Local organizations and Government in Igarapé-Miri, Mojú and Ourém took off in the middle of the 1990s. The partnership began in the middle of a serious economic and social crisis in the municipios that were based on agrarian sector.

[...] Igarapé-Miri was very, very, very poor [...]. A great crisis [...] The sugar cane cycle left us in a miserable condition, mainly the ribeirinha population (people who live by the river) [...]. (Local organisation leader in Igarapé-Miri).

[...] At the middle of 1990 s we were in a very poor condition [...] the município population survived only exploiting the natural resources [...]. (Local organisation leader in Mojú).

In that time [middle of 1990s], we were in a very difficult situation [...] Ourém always was poor, but after its reduction we became little and poorer [...] we had to find an alternative [...]. (Local organisation leader in Ourém).

From the 1950s to the end of 1980s, the economy of Igarapé-Miri and Moju were dominated by the exploitation of natural resources, specifically wood in the areas of terra firme and palm-heart (palmito) in the areas of várzea (LOBATO, 1985; MIRANDA, 2001). Minor itinerant agricultural cultivation of manioc in areas of terra firme was also produced in that 
period, however. For those reasons, there was a large-scale migration from the rural zones to urban areas particularly caused by the land expropriation from the rural workforces. Migration resulted in the enlargement of the urban population in both municípios. The population growth in urban areas resulted in a grave social crisis in the municipios that could not offer jobs, steady incomes and social services. Consequently, Igarapé-Miri and Mojú faced a significant increase in poverty.

In Ourém, there was a decrease in financial resources and grants for local Government administration because its municipal area had been reduced in order to create other municipios. The reduction of area resulted in a decrease of Ourém's population. Consequently, Ourém's income reduced as the transference of resources from federal government to municipio depends on the município's population.

$[\ldots]$ we had nothing to do in the city [...] there were no jobs [...] we lived asking for jobs and money from the preifeitura [...]. (Local organisation leader in Mojú).

[...] people were used to depending on the patron [...] during the years people worked in sugar cane just to have the minimum [...]. (Local organisation leader in Igarapé-Miri).

The relations between landowner and rural worker in the three municipios were characterized by exploitation of the workforces, patronage and coronelismo. Coincidently, the economic models in Igarapé-Miri, Mojú and Ourém were sustained for the economic elites that in many ways have played significant roles in the local political systems.

Supported by outsiders (the Catholic Church, an international NGO called MANI TESE and the Workers' Party), the landless in Igarapé-Miri started a countryside internal movement for land occupation and structural transformation. The group of people linked to the movement built up relationships with other groups in the region (associations and workers' unions of other municipios, including Mojú)) and also with national union federations and confederations. A group of leaders was provided with training in political skills from local Catholic Church leaders.

Initially, the movement in Igarapé-Miri resulted in the Rural Workers' Union (STR) controlling and later occupying unproductive areas. The Rural Workers' Union supported the creation of a grassroots organisation called Mutirão. This organisation aimed to build a cooperative form of production for the várzea communities.

Everything started from the Rural Worker Movement and the rural union conquest [...] The Church supported our cause [...]. They [Church members] helped us to create a project for collective production [...] we created Mutirão [...]. (Local organisation leader in Igarapé-Miri).

Mutirão received a grant from the Italian NGO MANI TESE. This credit supported Mutirão's infrastructure and programmes for political and administrative capacity building. The local Catholic Church in conjunction with its regional administration was responsible for project articulation. The initial capacity building process focused on forms of collective work and political articulation. Both the occupation by the Rural Workers' Union and the establishment of Mutirão formed a new political and economic scenario. In terms of economic production, rural workers gained control of their activities and both landless and small-scale, low-income producers were able to return to the rural zones.

Despite the number of landless involved in the social movements, these movements did not change the structure of the local state and the elites' control over local government. However, from the end of the 80s, both the Rural Workers' Union and Mutirão emerged as important local organizations to defend rural worker groups' interests and priorities in Igarapé-Miri and around. The linkages established with national and international NGOs supported the Rural Workers' Union and Mutirão's implementation of community development projects. These projects involved political and administrative training that heightened rural leaders' awareness of their own interests. Consequently, the Rural Workers' Union and Mutirão gained some political power and changed the political scenario.

Like other rural areas of north east Pará, in Ourém the conflict between rural workers and merchants to control rural production, credit access and land properties reached a peak in the 1980s. In that decade, peasants and rural worker movements spread all over 
north-east Pará and became dominant in various municípios. In Ourém the 1988 victory of the Rural Workers' Union in direct elections was one of the pioneering moments in northeast Pará. The municipio reduction was of benefit here to rural workers movement since a great part of the area (and part of the rural workers' jurisdiction) was transferred to the município of Garrafão do Norte. Coincidently or not, most of traditional local elites were transferred to Garrafão do Norte.

As soon as the new Rural Workers' Union administration took place, it implemented a key aim of partnership between the union and isolated rural communities. This initiative, which had support of the NGO FASE, had as its goal the implementation of a new system of production beyond that of the traditional cultivation of manioc. FASE received financial support from the international NGO MANI TESE and promoted capacity building in technological, associational and market terms. The first community-based association that was created was 25 de Julho. FASE supported such processes in all forms and emphasised collective work.

The second of Ourém's Rural Workers Union victories in direct elections was the administration of the COMAG (High Guama River Mixed Agro-Cattle Cooperative). This victory aimed to control COMAG, an organisation that since its creation was managed by large farmers and merchants rather than rural workers or peasants. The goal of controlling COMAG was to link small-scale agricultural production with a micro-manufacturing process and access to markets without a middle man (atravessador). The main role of COMAG in supporting the small-scale producers was to buy their produce at market price (increasing their income) and to break their dependence on the atravessador.

The productive and political environment created in Ourém by the Rural Workers' Union, MSTR and COMAG politically empowered small-scale producers at community level. However, such empowerment was restricted to 16 rural communities and was linked to external actors and a credit programme. MSTR and the rural unions' leaders took the decision to participate in the political sphere and linked to a left-wing workers' party. As part of their aim for scaling up small- scale rural producers' requirements it was deemed necessary to take part in the formal political process. They agreed to a political alliance with leaders of other parties to confront the prefeito's party in the 1996 elections. Such strategy was successful and was an important factor in the partnership between civil society and local government later on.

From 1993, the FNO developed its second phase (1993 - 1996) which prioritised supporting family-based, small-scale producers. In order to be implemented, the rules of FNO required the creation of grassroots organizations to support potential small- and lowincome borrowers. For the banks' financing system, the establishment of grassroots organizations would create a shared obligation between low-income borrowers. As a result of this financing, between 1993 and 1996, new local organizations were created (grassroots organizations, cooperatives and associations) in Igarapé-Miri, Ourém and Mojú.

If on the one hand, the growth of local organizations raised rural areas' social capital with the formation of networks between local organizations and regional and local Governments, on the other hand it had two important consequences. Firstly, it strengthened relationships between local organizations and local Government, and secondly, it weakened the relations between rural communities and the Rural Workers' Union.

The creation of new grassroots organizations was a new form of local Government empowerment. Financial dependency and political subordination exercised by local Government officials over these new grassroots organizations were the price of relying on the resources provided by the local Government. The new local organizations did not have the independent means to act on their own initiative and they became ineffective in articulating the interests of their members. As stated by Esman and Uphoff (1984), the consequence of government dependency is usually a passive and even alienated community. Co-optation of the local organizations by the local Government to follow the local state ideas, conceptions and above all the interests of a particular local Government leader was very frequent. The level of cooperation established between the local Government and the new associations 
was a way to reinforce the power of the local Government leaders.

The idea of cooperation for local development in Igarapé-Miri emerged in the end of 1990s when there was growth of agricultural production from both Mutirão and the associations that had got FNO credit. Such growth, allied with the improvement in local organizations' structure, motivated the labour union and Mutirão to try to form a cooperative for micro-manufacturing processes and market access. However, the idea of the creation of a cooperative was taken up by local government. Local government asked the Federal University of Pará (UFPA) to provide technical support, particularly from staff of the Poverty and Environment Programme (POEMA). The local Government - POEMA partnership aimed to use POEMA's technical support for cooperative building using prefeitura financing.

POEMA performed the municipio's participatory diagnosis and enlarged the partnership to include local communities, involving the communities of the terra de várzea and their associations. The result was a project for cooperative foundation. Despite disagreement between local Government, the Rural Workers' Union and Mutirão, the latter two participated actively in the diagnosis process and in cooperative projection. POEMA's directive facilitated local Government and local organizations to come together to achieve a common aim of cooperative creation. POEMA also facilitated negotiations with different institutions to get credit. Local Government links with high levels of Pará Government also helped in getting finance. However, the cooperative became very dependent on $\mathrm{PO}-$ EMA. The cooperative members had insufficient political capacity to articulate the views of rural communities and its members and to manage the cooperative itself, both financially and technologically.

Local state - local organizations' partnership for rural development in Ourém started in 1996 when the federal Government launched the PRONAF programme, particularly the subprogram PRONAF-Infrastructure and Municipal Service Support. To take part in this subprogram each município had to create its own rural development committee and its own municipal plan for rural development.
Along with the possibility of PRONAFInfrastructure grants, a combination of two other factors was significant in creating a partnership between local Government and local organizations. The urban area population increased from $21 \%$ to $47.29 \%$ and the young population (from 0 to 14 years old) reached $43.6 \%$ of the total population, demanding more public service delivery. The reduction in size of Ourém affected only the rural area and the urban geographical configuration did not change. As a municipio where the economy is based on the rural sector, the shift in the urban-rural ratio illustrates the economic and social impact that geographical reductions had in Ourém. The socio-economic scenario drove Ourém's rural movement to join with the regional rural movement and to request alternative forms of credit and other incentives for family-based small-scale, rural producers. Secondly, BASA supported 155 cultivation projects and also supported the regeneration of the municipal cooperative for agricultural production during the first phase of implementation of FNO. The number of community-based associations increased at the end of 1997 as a direct result of FNO. The creation of associations was a sine qua non for credit acquisition. In Ourém, the new associations were created with the support of the local Rural Workers' Union. As the Rural Workers' Union had strong links with external NGOs, MSTR and the Workers' Party, such factors were relevant to the inclusion of different interest groups.

We already had started mobilization for creation of new associations when the FNO requested it [...] we had experience with communities [...] We were well organized when we knew about the credit [...] So, it was easy to ask the Prefeitura [council] to come [...] They were very afraid to come along, but they came [...]. (Leader of a local organisation in Ourém).

Partnership with local organizations was a fruitful and important strategy for local Government to enlarge its budget. In spite of some disagreements between local Government bodies and the civil society representatives in the Rural Development Committee during the planning phase, this strategy was able to attract resources to the município. The strategy was also able to promote local Government partnerships with rural communities 
and local organizations politically guided by the Rural Workers' Union including the associations of 25 de Julho and Limão.

[...] because there was an aim for that partnership. [...] There were political differences [political parties' differences], but it [partnership] was interesting to everybody $[\ldots]$, the committee attracted money to the municipio. (Former head of the Municipal Department of Agriculture in Ourém).

[...] we worked with the Government with no problems [...] our aim was to improve the livelihood of our community [...]. (Former head of the Limão association in Ourém).

In spite of party political links with regional and federal Government, local Government in Ourém carried out independent methods of political administration. This method involved both political ties with high levels of Government and a workable network with local leaders linked to rural social movements and community-based organizations. On the one hand this strategy caused the local Government to be politically vulnerable; on the other hand it promoted more links with family-based, small-scale producers. The link with family-based, small-scale producers facilitated access to financial resources in the municipio and made these resources matters of public supervision. While public supervision of resources brought public participation in governance, this participation would be also the object of power sharing. However, as possibilities for power sharing are a cause of conflicts between local Government and local organizations.

Initially, the state-civil society partnership was established with minor struggles. The committee was able to write up the First Plan for Municipal Development (PMD) (1997 -2000) by consolidating different projects already supported by the FNO. In spite of great progress in terms of state-civil society relationships and the creation of a joint plan, this plan did not encompass the diverse issues that traditionally belong to municipal planning. It concentrated solely on rural production, particularly on agricultural production. Other important issues such as education and health were not focused on. Additionally, vague aims were outlined and no targets were established. However, the main target of getting federal resources to the municipio was achieved. Ourém received credit corresponding to US $\$ 314,730.00$ for infrastructure improvement. This amount was delivered in lump sums according to the project's approval. The Prefeitura (council) added $10 \%$ of the amount to deal with the total project expenses. The plan was considered innovative in the State of Pará and at that time was regarded by the official and non-governmental agencies as an example of state-civil society partnership to be followed by other municipios.

However, the execution of the plan brought many power disputes. From the end of the first plan for rural development (2000) the partnership gradually eroded. In spite of different interests inside the Rural Development Committee, this committee was able to join forces to create a more focused planning document for family-based agriculture production (Sustainable Development Plan for Family-based Agriculture in Ourém) (2000-2003), so far the local state and local organizations have not yet found the means to reconcile their different interests.

Power disputes in partnership cases have emerged at various levels; disputes over political power, finances, knowledge and so on. In this study on concepts of local power, it is the convergence of diverse levels of power that emerges as the cause of most friction between all organizations involved in the process of partnership. The two following examples illustrate some of the power disputes. For instance, power disputes about types of production emerged during the phase of PDR planning in Ourém (2000). While rural communities wanted to maintain traditional types of production such as manioc and chilli, the policy of credit fixed the financing exclusively to fruit production. Despite an absence of knowledge about fruit production, the rural communities accepted this condition. The result, however, was disappointing. Many rural producers did not know much about the production of fruit and were not able to cultivate and produce what was planned.

[...] we do not know how many, but we had many producers that failed [...] they did not grow fruit well and the EMATER [governmental body for technical agriculture support] did not do well either [...] We cultivated bananas, but it was a failure [...]. (Former head of the Rural Development Committee in Ourem). 
During the implementation of the plan other differences emerged. For example, the CDR established that although the Prefeitura was managing the project, the use of resources had to be accepted by the committee. However, such a condition was not attractive to local Government. According to local Government bodies, it caused the prefeito to depend on the Rural Development Committee and this caused political and administrative constraints.

Others issues of conflict also existed. However, what is sufficient to conclude in this section is that despite emergence of power conflicts, cooperation between local Government and civil society did not come as a natural process, but as part of a political process which includes a convergence between social movements and policy changes.

\section{Conclusion}

The historical background to social movements and policy changes is a helpful means of clarifying the emergence of partnership between the state and civil society in Pará. Although social movements are part of a relation of conflict between state and society, in Pará they were a precondition for changes in public policy, financing and in the priorities of regional agencies that resulted in propositions for cooperation between local Government and local organizations at município level.

The historical analysis of the cases demonstrated that cooperation between local Government and local organizations only took place when rural requirements were scaled up from social movements to the political sphere. Such evidence points out that in areas with robust vertical social structures based on relations of power, such as in IgarapéMiri, Mojú and Ourém, cooperation firstly depends on political constructions of social capital (political networks) and secondly on changes in the public policy structure. In the cases analysed, cooperation between local state and civil society only took place when the financing structure required them to work together. However, this cooperation decreased as soon as the resources available for this cooperation ended. Such disappointment implies that cooperation based on the regula- tions of a financing system is time limited and may be ineffective for long term objectives.

Political constructions of social capital depended on the creation of building blocks of local organizations that represented the interests of excluded groups of rural people. The presence of external actors was fundamental to strengthening the political power of local organizations such as the Mutirão in Igarapé-Miri and 25 de Julho in Ourém. Both cases, Igarapé-Miri and Ourém show that external support was crucial for strengthening local organizations. This demonstrates that without capacity building for political activity and economic independence, local organizations may still be forced into vertical structures of power and/ or be reliant on local government.

In spite of the importance of establishing networks between local organizations and external actors for building political activity and economic independence for rural communities, links with the political sphere were fundamental in order to achieve broad aims. Without participation in the formal political arena a rural development concept that prioritises small-scale, low-income producers is more difficult to put into practice.

However, rural development is embedded in social structures and is monitored by state rules, policy and actions that in practice may facilitate or make difficult rural development cooperation. In the cases of IgarapéMiri, Mojú and Ourém, it was observed that at the same time that state policy created favourable conditions for cooperation between civil society and state, local Government, acting on its own power interests, created dependent and weak local organizations. On the other hand, politically capable local organizations act as permanent opposition to the local Government. They often look for opponent actors of governance in order to gain support to confront the dominant powers. As noted in the cases, links with political opponents of the Government has influenced the decision making of local organizations.

When local organizations act inside social movements the possibilities for cooperation with Government is weak. In contrast, when local organizations scale up from a social movement to the political sphere the possibilities for sharing a common aim with 
local Government is much more plausible. It shows that cooperation is less plausible in an environment of political conflict of power even if both sides have common aims. The matter that emerges in building partnership in an environment of political conflict is how to define common ground without making political disadvantages for either local Government or local organizations.

Cooperation in Pará is the product of institutionalised cooperation. For a region with little tradition of joint community-state cooperation, the actual pattern and implementation of partnership is likely to be critically important for initiatives that encourage rural communities to organize their own requirements for local development. Partnership between local organizations and local Government emerged in an environment of fragile trust where power disputes weakened the opportunity to create a prospect of a secure and long-term future for excluded groups of rural people.

\section{Bibliography}

ABRAMOVAY, R. Conselho além dos limites. Seminário Desenvolvimento Local e Conselhos Municipais de Desenvolvimento. Porto Alegre: Seminário Desenvolvimento Local, 2002.

BASA. Relatório de Gestão do FNO 2002. Belém: Banco da Amazônia S.A., 2002. Available at: <www.basa. com.br/decon/relgestaoFNO2002.doc $>$. Accessed on: 20 may 2005.

BNDS. Receita muicipal: a importância das transferencias do FPM e do SUS. Informe-se, 2001. Available at: <www.bnds.gov.br/conhecimento/informeSF/Inf_28. pdf $>$. Accessed on: 25 may 2005.

BEBBINGTON, A. Capitals and capabilities: a framework for analyzing peasant viability, rural livelihoods and poverty. World Development 12: 2021-2044, 1999.

BOWYER, T.J. Popular participation and the State: democratising the health sector in rural Peru. PhD. University of London, 2003.

BOWYER, T. Public space, inequality and health: interaction and social welfare in rural Peru. International Relations 19(4): 475-492, 2005.

Social Capital and Health: a rural perspective. In: HUQUE, A.S.; ZAFARULLAH, H. (Eds.). International Development Governance. Boca Raton: Taylor \& Francis, 2006.

COLEMAN, J.S. Foundations of Social Theory. London: Harvard University, 1990.

DALLA-NORA, H.A. A organização sindical rural no Rio Grande do Sul e o surgimento do Sindicato dos Trabalhadores Rurais de Frederico Westphalen (1960-1970). Passo Fundo: UPF, 2002
EVANS, P. Government action, social capital and development: reviewing the evidence on synergy. In EVANS, P. (Ed.) State-society Synergy: government and social capital in development. Berkeley: University of California, 1997.

ENGBERG-PEDERSEN, L. The limitations of political space in Burkina Faso: local organizations, decentralisation and poverty reduction. In: WEBSTER, N.; ENGBERG-PEDERSEN, L. (Eds.). In the name of the Poor: Contesting Political Space for Poverty Reduction. London: Zed Books, 2002.

ENGBERG-PEDERSEN, L.; WEBSTER, N. (Eds.). In the name of the Poor: Contesting Political Space for Poverty Reduction. London: Zed Books, 2002.

ESMAN, M.; UPHOFF, N. Local organizations: intermediaries in rural development. Cornell: Cornell University, 1984.

FARRINGTON, J.; BEBBINGTON, A. Reluctant partners?: non-governmental organizations, the state and sustainable agricultural development. London: Routledge, 1993.

FINE, B. Social Capital versus Social Theory: political economy and social science at the turn of the millennium. London: Routledge, 2001.

FOX, J. Governance and rural democratisation in Mexico: state intervention and public accountability. Development Studies 32(1), 1995.

How does civil society thicken? The political construction of social capital in rural Mexico. In: EVANS, P. (Ed.) State-society Synergy: government and social capital in development. Berkeley: University of California, 1997.

FOWLER, A. Striking a balance: a guide to enhancing the effectiveness of non-governmental organizations in international development. London: Earthscan, 1997.

GILCHRIST, A. The well-connected community. Bristol: Community Development Foundation, 2004.

GRZYBOWSKI, C. Caminhos e descaminhos dos movimentos sociais no campo. Petrópolis: Vozes, 1987.

IBAM. Projeções do repasse do FPM. Rio de Janeiro: IBAM, 2008.

ISHAM, J. et al. Social capital and economic development: well-being in developing countries. Cheltenham: Edward Elgar, 2002.

LOBATO, E. Caminho de canoa quebrada. Belém: Imprensa Oficial do Pará, 1985.

MATTEI, L. Programa Nacional de Fortalecimento da Agricultura Familiar (PRONAF): concepção, abrangência e limites. ENCONTRO DA SOCIEDADE BRASILEIRA DE SISTEMAS DE PRODUÇÃO, 4. Belém: SBSP, 2001.

MIRANDA, H.R.de. Diagnóstico participativo: a experiência de Igarapé-Miri. Belém: UEPA/POEMAR, 2001.

MONTEIRO, R. Informação e redes de integração no novo ciclo de mobilizações dos pequenos agricultores da Transamazônia. Mphil. NAEA. Belém: UFPA, 1996.

OAKLEY, P. People's participation in development projects. INTRAC 7, 1995. 
OLIVEIRA, H.C.; DOMINGUES, E.P. Considerações sobre o impacto dos fundos constitucionais de financiamento do norte e do centro-oeste na redução da desigualdade regional no Brasil. ANPEC 2005. Anais... Available at: <www.anpec.org.br/encontro2005/artigos/A05A122pdf>. Accessed on: 22 may 2005.

PUTNAM, R. Making democracy work: civic tradition in modern Italy. Princeton: Princeton University Press, 1993.

Democracies in flux: the evolution of social capital in contemporary society. Oxford: Oxford University Press, 2002.

SEN, A. Development as freedom. Oxford: Oxford University Press, 1999.

TENDLER, J. Good Governance in the tropics. Baltimore: John Hopkins, 1997.

TURA, L. R. Atores sociais e suporte institucional dos projetos do FNO-Especial, 2000. In: TURA, L. R.; COSTA, F. de A. (Eds.). Campesinato e Estado na Amazônia. Brasília: Brasília Jurídica/FASE, 2000.
. Notas introdutórias sobre os Fundos Constitucionais de Financiamento e sua configuração na Regiao Norte. In: TURA, L. R.; COSTA, F. de A. Campesinato e Estado na Amazônia. Brasília: Brasília Jurídica/FASE, 2000a. p. 29-46.

. Atores sociais e suporte institucional dos projetos do FNO-Especial. In: TURA, L. R.; COSTA, F. de A. Campesinato e Estado na Amazônia. Brasília: Brasília Jurídica/FASE, 2000b. p 271-322.

. Gritos do campo: reconhecimento político e exercícios de cidadania no Pará. Mphil. PPGS/IFCS. Rio de Janeiro: Universidade Federal do Rio de Janeiro, 1996.

VASCONCELLOS, A. M. de A. Transformações sociais e lutas cotidianas no laranjal em Barcarena. Belém: UNAMA, 1996.

VASCONCELLOS SOBRINHO, Mário. Partnership for Local Development: the relationship between local organizations and government in two areas of North-East Pará, Amazonia, Brazil. Saarbrücken: VDM Verlag Dr. Müller, 2009.

\section{List of Acronyms and Abbreviations}

BASA

CMDR

CEPLAC

COMAG

COOPFRUT

EMATER

FASE

FNO

FNO Rural-Especial

FUNRURAL

MANI TESE

MDA

MSTR

NGO

PDR
Banco da Amazônia S.A.

Bank of Amazonia plc.

Conselho Municipal de Desenvolvimento Rural

Municipal Committee for Rural Development

Comissão Executiva do Plano da Lavoura Cacaueira

Executive Commission of Cocoa Farming

Cooperativa Mista Agropecuária do Alto Rio Guamá

High Guama River Mixed Agro-Cattle Cooperative

Cooperativa Mista de Pequenos Produtores Rurais de Igarapé-Miri

Igarapé-Miri Co-operative of Small Rural Producers

Empresa de Assistência Técnica e Extensão Rural

Institute of Technical Assistance and Rural Services Support

Federação de Órgãos para Assistencia Social e Educacional

Federation of Social and Education Assistance Agencies

Fundo Constitucional de Financiamento do Norte

Constitutional Fund for Financing the Northern Region

Fundo Constitucional do Norte Especial para a Área Rural Special FNO for Rural Area

Fundo de Assistência e Previdência do Trabalhador Rural

Fund for the Assistance and Insurance of Rural Workers

Associazione Mani Tese

Mani Tese Association

Ministério do Desenvolvimento Agrário

Ministry of Agrarian Development

Movimento Sindical dos Trabalhadores Rurais

Rural Workers' Union Movement

Organização Não Governamental

Non-Governmental Organisation

Programa de Desenvolvimento Rural

Rural Development Programme 
PMD

POEMA

PRONAF

SAF

STR

SUDAM

SUFRAMA

UFPA
Plano Municipal de Desenvolvimento

Municipal Development Plan

Programa Pobreza e Meio Ambiente

Poverty and Environment Programme

Programa Nacional de Fortalecimento da Agricultura Familiar National Support Programme for Family-Based Agriculture

Secretaria da Agricultura Familiar

Department of Family-based Agriculture

Sindicato dos Trabalhadores Rurais

Rural Workers' Union

Superintendência do Desenvolvimento da Amazônia

Superintendence for Amazonia Development

Superintendência da Zona Franca de Manaus

Manaus Superintendence of Free Trade

Universidade Federal do Pará

Federal University of Pará 